\title{
Construction of Virtual Simulation Experiment Platform for Operation Research and Cybernetics
}

\author{
Lili Yang \\ The Department of General Education, The College of Arts and Sciences Yunnan Normal University, \\ Kunming, Yunnan, 650000, China
}

Keywords: Operations Research and Cybernetics, Virtual Simulation, Experimental Teaching.

\begin{abstract}
Operational research and integration of operational research, control science and information science of new interdisciplinary issues. The traditional classroom demonstration and experimental education, combined with the help of virtual simulation technology to build virtual simulation experimental education, students' practical skills to improve a strong complement and effective methods. The advantages of virtual simulation experiment education of university operation research and cybernetics expert training are analyzed, the construction methods of appropriate virtual simulation experiment platform are discussed, and the basis of cybernetics expert training is studied and applied.
\end{abstract}

\section{Introduction}

As an important direction of information and computing science, operations research and cybernetics, system analysis, information processing, as the basis of cybernetics, establish the mathematical model and computer processing method of the system, analyze and solve production. Various types of master plans for mathematical modeling, systems analysis, and life systems (economic analysis, financial systems, military machines, production management models)[1]. In recent years, the new research trend that combines operation research, system research and information science has attracted much attention. This major focuses on training talents who have the ability to solve practical problems in engineering, modeling the system according to actual problems, providing model-based control strategies, and possessing practical skills[2]. Therefore, in operational research and cybernetic guidance, we should not only pay attention to the cultivation of theoretical knowledge, but also to the cultivation of practical design, practical ability and innovation ability.

\section{The Necessity of Introducing Virtual Simulation Teaching}

Traditional practical ability training usually has two methods: give students an experimental instruction, and provide a kit in the laboratory for instruction experiments. In the process of the experiment, students only need to refer to the experimental instruction to connect the system and complete the experiment according to the steps. Through installation, testing and debugging, the theory and practice are organically combined to improve the practical skills of students. The former has few mobile phones and cannot combine theoretical knowledge with practical system. Students can't think deeply and use the theoretical knowledge learned in class to solve practical problems. The latter is limited by the number and diversity of equipment, which takes a long time[3]. Class time is too long, consumption of consumables is large and cost is high. Under the severe financing situation, it is very difficult to achieve and popularize it. With the development of computer technology, simulation technology is gradually mature. After mathematical reasoning and scientific experiments, understanding the laws of nature is the third basic method. Virtual simulation education is gradually introduced into the guidance process. The so-called virtual simulation education allows the use of real systems and computer software models to simulate real situations and learn in a simulated environment. This distinct education method is the actual work scene and the engineering system close to the reality. It is to improve the interest of students. Students can 
combine the work scene in a short period of time, experience the design, control the feeling, and act effectively in real life[4]. In order to master the operation technology faster. In addition, in this study, we make use of the advantages of computer software, make flexible and diverse scenes more practical scenes, experience the application of theoretical knowledge learned in various scenes, and deepen students' deep knowledge understanding and comprehensive utilization.

Table 1 Curriculum system of virtual design

\begin{tabular}{|c|c|c|c|}
\hline Website & $\begin{array}{c}\text { Total number } \\
\text { of courses }\end{array}$ & $\begin{array}{c}\text { Physical education courses in } \\
\text { domestic colleges and } \\
\text { Universities }\end{array}$ & $\begin{array}{c}\text { Proportion of total } \\
\text { courses on the website }\end{array}$ \\
\hline Peking University open class & 49 & 0 & 0.00 \\
\hline School Online & 181 & 319 & 3.10 \\
\hline $\begin{array}{c}\text { Five minute course network of } \\
\text { National Open University }\end{array}$ & 10220 & 1 & 0.00 \\
\hline $\begin{array}{c}\text { Curriculum Sharing Alliance of } \\
\text { eastern and Western } \\
\text { Universities }\end{array}$ & 53 & 7 & 0.67 \\
\hline Love Curriculum & 1038 & 374 & 1.84 \\
\hline $\begin{array}{c}\text { National Excellent Course } \\
\text { Resource Network }\end{array}$ & 20272 & 0 & 0.00 \\
\hline $\begin{array}{c}\text { China Education online open } \\
\text { resource platform }\end{array}$ & 214 & 0 & 0.00 \\
\hline $\begin{array}{c}\text { CCTV China University video } \\
\text { open course }\end{array}$ & 124 & 2 & 2 \\
\hline
\end{tabular}

\section{Research Status of Virtual Simulation Experiment Platform}

At present, virtual simulation technology is widely used at home and abroad, in curriculum guidance, medical research, sports training, military and other fields. In classroom teaching, virtual simulation platform provides people with ideal teaching methods[5]. The United States, which started in the United States, has advanced international level in virtual simulation technology. As for classroom teaching, the United States is the first country to introduce the application of virtual simulation in classroom teaching and gradually establish a mature virtual simulation platform [5]. For example, the University of Carolina uses Java technology to establish the Institute of virtual physics, which includes virtual experimental equipment, corresponding experimental courses and experimental evaluation and collaboration modules. In Europe, the UK is a leader in virtual simulation technology. The UK is a leader in developing software packages based on virtual simulation technology, which can be used for classroom teaching and industrial production. The University of Nottingham has studied desktop virtual input devices for normal physical and learning disabilities as well as classroom research for some students. In China, universities and research institutions are also conducting research on virtual simulation experiment platform. The purpose of this study is to use virtual simulation technology to virtualize the real scene, and to carry out corresponding education and operation simulation. For example, the University of science and technology of China has developed the first education system based on virtual simulation. The system constructs a geometric optics experiment platform based on virtual simulation technology. This virtual simulation experiment platform is a combination of physical teaching aids, computer technology and virtual simulation technology. Beijing runnier Network Technology Co.Ltd. is based on three advantages of Peking University, such as network, communication, electronics, etc. Using java applet technology, B / S structure, J 2ee framework. After a long-term research on electric power, a supporting virtual experiment system which can run on campus network has been developed. By comparing the virtual simulation education systems at home and abroad, we can see that the foreign language online experiment is more than 10 years earlier than the domestic development, with rich equipment and functions[6]. But the price of foreign software products is too high, the technical difficulty is not suitable for students, suitable for engineers. Many mature 
foreign experimental products do not support network operation, do not support education management and knowledge support learning, and can only be installed and run independently on the local computer. The virtual simulation teaching software of Beijing post and telecommunications has greatly improved these defects and is suitable for the experimental teaching needs of domestic universities and colleges.

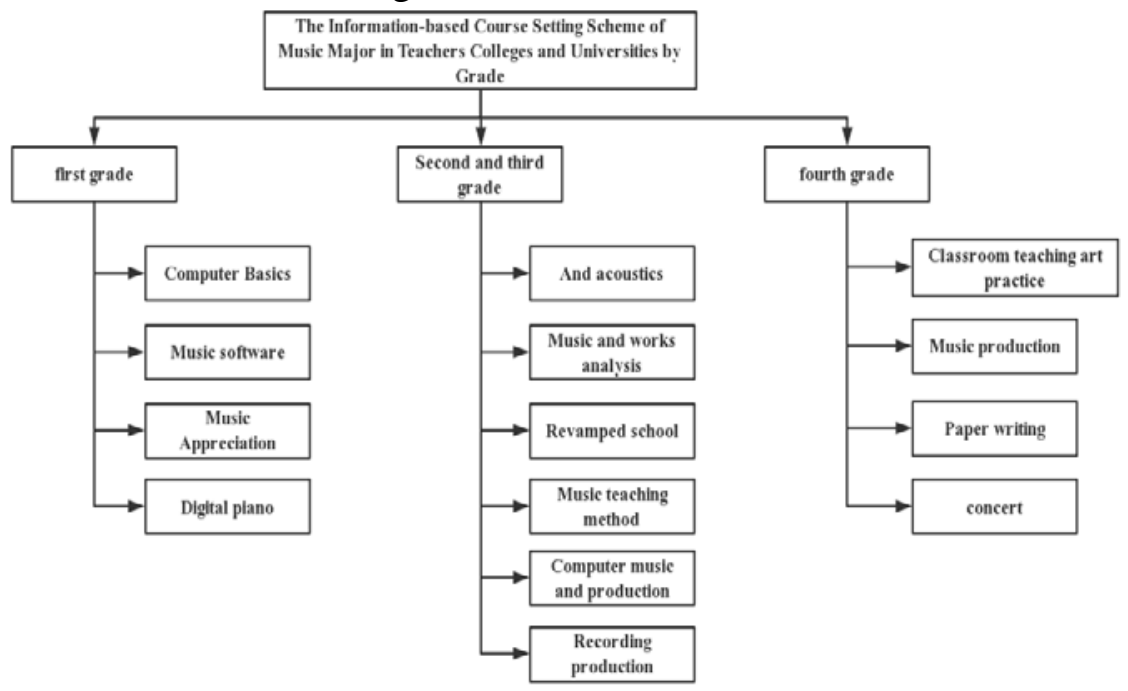

Figure 1 Curriculum system of virtual design

\section{Construction Plan of Virtual Simulation Experiment Platform for Operation Research and Cybernetics}

It is very difficult for students to demonstrate the theoretical abstraction of operation research and logic course in class, and they can't really understand it[7]. In order to use a practical system to help students grasp theoretical knowledge in practical education, it is very difficult to demonstrate physics. In order to solve the contradiction between the traditional theory of physical demonstration and the practical ability of students, it is necessary to build a virtual simulation experiment platform. The virtual simulation experiment platform combines the characteristics of operation research and virtual specialty, and has good intuitiveness, high precision and simple operation. In the specific implementation process, according to the actual situation of operation research and virtual education, the virtual simulation experiment platform is configured as follows:

\subsection{Scientific Analysis of Students' Characteristics and Employment Needs}

At the same time, we should strengthen the reform of content and guidance methods. In the construction of the experimental platform, the combination of the latest technology, the first time and the operation situation, the demand research of the main enterprises and the learning characteristics of cybernetics major, and the simulation software of virtual scene are used for the purpose of constructing the education situation close to the reality[8]. In classroom teaching, we should combine all kinds of advanced teaching methods organically to improve the effect of classroom teaching.

\subsection{Actively Explore}

Establish virtual simulation teaching mode. Modern control theory, digital control, and the important professional courses of the best control, through the investigation and analysis of the actual system simulation environment, in order to find the appropriate simulation software, for the specific stereotyped education plan, please teach the best application method of the virtual simulation education exploration on the special site, which is suitable for the activities.

Relevant contents are shown in the table below. 
Table 2 Analysis of virtual design curriculum system

\begin{tabular}{|c|c|c|}
\hline Schedule & $\begin{array}{c}\text { Smartclassroom teaching activity } \\
\text { organization }\end{array}$ & Theoretical guidance \\
\hline \multirow[t]{3}{*}{$\begin{array}{l}\text { Before } \\
\text { class }\end{array}$} & $\begin{array}{l}\text { Use mobile phone learning platform for } \\
\text { academic analysis and strategy guidance }\end{array}$ & $\begin{array}{l}\text { Cognitive strategies, establishing } \\
\text { learning goals, and developing } \\
\text { learning plans }\end{array}$ \\
\hline & $\begin{array}{l}\text { Learning platform uploading study case, } \\
\text { micro-teaching instructional video, online } \\
\text { placement task requirements }\end{array}$ & Input - noted input \\
\hline & $\begin{array}{c}\text { Mobile phone questionnaire voting, pre- } \\
\text { heating before class }\end{array}$ & Interactive + Input \\
\hline \multirow[t]{3}{*}{ In class } & $\begin{array}{l}\text { Classroom lectures, practice discussions, } \\
\text { online and offline mixed teaching }\end{array}$ & $\begin{array}{l}\text { Understand input + absorption } \\
\text { internalization language }\end{array}$ \\
\hline & Group collaboration and mutual learning & $\begin{array}{c}\text { Absorption internalization } \\
\text { language + cooperation strategy }\end{array}$ \\
\hline & $\begin{array}{l}\text { Learn online online, upload recordings, } \\
\text { videos }\end{array}$ & Processing + output \\
\hline \multirow[t]{3}{*}{$\begin{array}{l}\text { After } \\
\text { class }\end{array}$} & $\begin{array}{c}\text { Complete learning platform work, unit } \\
\text { testing }\end{array}$ & Output + teaching effect detection \\
\hline & $\begin{array}{l}\text { Complete the mobile phone questionnaire } \\
\text { and reflect after class }\end{array}$ & $\begin{array}{c}\text { Cognitive strategy, assessing } \\
\text { learning outcomes }\end{array}$ \\
\hline & $\begin{array}{l}\text { Organize online extracurricular activities to } \\
\text { create a diverse locale }\end{array}$ & $\begin{array}{c}\text { Intentional learning + companion } \\
\text { learning }\end{array}$ \\
\hline
\end{tabular}

\subsection{School Enterprise Cooperation}

It is particularly important to jointly establish a high experimental education foundation, so that students can access more work scenes in limited time and conditions[9]. Virtual simulation education has strong scalability and openness, and can provide flexible and diverse work programs. In order to produce more realistic work scripts, please work closely with the company.

\subsection{Loint Efforts of Teachers And Students}

To create the most reasonable virtual teaching environment, develop the virtual simulation teaching environment and the corresponding experimental teaching software.

\section{Conclusion}

According to the necessity of practical operation education, there are still many places to study the necessary operation of reform and guide cybernetics. In this paper, the specific goal and implementation method of establishing an operation oriented research and virtual simulation experiment platform are proposed[10]. Through a complete survey, teachers and students, are the practical ability of students as the training goal, intuitive, high-precision, simple operation and highlevel education platform of virtual simulation experiment in order to build an action.

\section{References}

[1] Nighat, Shah., Lubna, Baig., Nusrat, Shah., Simulation based medical education; teaching normal delivery on intermediate fidelity simulator to medical students. Jpma the Journal of the Pakistan Medical Association, vol. 67, no. 10, pp. 1476-1481, 2017.

[2] Jun, Tian., Yu, Yang., Li-Ping, Zhang,. Ratcheting Behavior of SA508-3 Steel at Elevated Temperature: Experimental Observation and Simulation. Acta Metallurgica Sinica(English Letters), vol. 30, no. 9, pp. 822-828, 2017.

[3] A.Z. Ibitoye, T. Orotoye, E.O. Nwoye, Analysis of efficiency of different antennas for microwave ablation using simulation and experimental methods. Egyptian Journal of Basic \& 
Applied Sciences, vol. 5, no. 1, 2018.

[4] Michael, P. Brundage., Qing, Chang., Yang, Li., Implementing a Real-Time, Energy-Efficient Control Methodology to Maximize Manufacturing Profits. IEEE Transactions on Systems Man \& Cybernetics Systems, vol. 46, no. 6, pp. 855-866, 2017.

[5] XUE, Ke-min., SUN, Da-zhi., LI, Ping. Numerical simulation and experimental research on hydro-bulging of automobile drive axle housing. Suxing Gongcheng Xuebao/journal of Plasticity Engineering, 2017.

[6] X, Guo., Y, Zhang., S, Jiang, Experimental Research and Numerical Simulation of Bearing Capacity of a New Type of Occlusive High Strength Bolt Shear Connection. Journal of Tongji University, vol. 45, no. 4, pp. 472-480, 2017.

[7] Lei, Li., Hao, Yan., Hengxuan, Zhang., Numerical simulation and experimental research of the flow force and forced vibration in the nozzle-flapper valve. Mechanical Systems \& Signal Processing, no. 99, pp. 550-566, 2018.

[8] Jun, Zhu., Chao, Wang., Junle, Yu., Optical simulation and experimental determination of the effect of subcell sequence in tetraphenyldibenzoperiflantheneand phthalocyanine - based tandem solar cells. Physica Status Solidi, vol. 214, no. 10, 2017.

[9] M. Li, Z. Li, D. Qin, Experimental Research and Numerical Simulation of Flow Field in a GasLiquid Countercurr Scrubber. Guocheng Gongcheng Xuebao/the Chinese Journal of Process Engineering, vol. 17, no. 4, pp. 689-696, 2017.

[10] Katelyn, Stepan., Joshua, Zeiger., Stephanie, Hanchuk., Jun, Zhu., Chao, Wang. Immersive virtual reality as a teaching tool for neuroanatomy: Immersive VR as a neuroanatomy teaching tool. International Forum of Allergy \& Rhinology, vol. 7, no. 3, 2017. 